This item was submitted to Loughborough's Research Repository by the author.

Items in Figshare are protected by copyright, with all rights reserved, unless otherwise indicated.

\title{
Making psychology relevant
}

PLEASE CITE THE PUBLISHED VERSION

http://dx.doi.org/10.1177/0957926505054944

PUBLISHER

(c) Sage Publications

VERSION

AM (Accepted Manuscript)

LICENCE

CC BY-NC-ND 4.0

REPOSITORY RECORD

Potter, Jonathan. 2019. "Making Psychology Relevant". figshare. https://hdl.handle.net/2134/9530. 
This item was submitted to Loughborough's Institutional Repository (https://dspace.lboro.ac.uk/) by the author and is made available under the following Creative Commons Licence conditions.

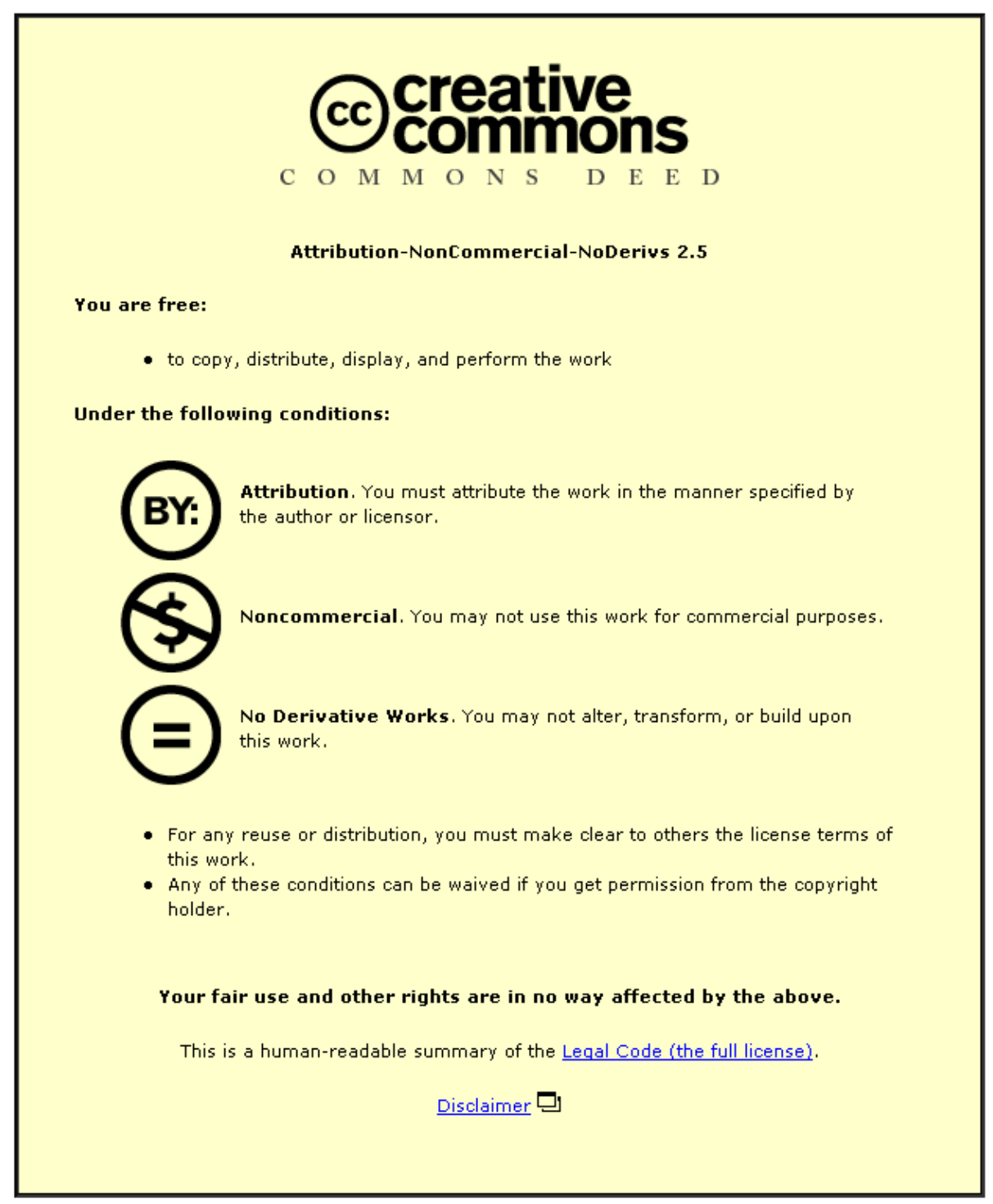

For the full text of this licence, please go to: http://creativecommons.org/licenses/by-nc-nd/2.5/ 


\section{Making Psychology Relevant}

\section{Jonathan Potter}

Discourse and Rhetoric Group

Department of Social Sciences

Loughborough University

Loughborough

Leicestershire, LE11 3TU

To appear in: Discourse \& Society
Email: J.A.Potter@lboro.ac.uk

Tel: 01509223384

Fax: 01509223944

17 March 2012 


\title{
Making Psychology Relevant
}

\begin{abstract}
This paper describes some key features of a discursive psychological approach. In particular, discursive psychology is analytically focused on the way psychological phenomena are practical, accountable, situated, embodied and displayed. It describes its particular version of constructionism and its distinctive approach to cognition as points of contrast with a range of other perspectives, including critical discourse analysis, sociolinguistics, ethnomethodology and conversation analysis. Finally, it describes three areas where discursive psychology is involved with social critique: work on categories and prejudice; issues to do with cognitivism and its problems; and work developing a discursive psychology of institutions.
\end{abstract}




\section{Making Psychology Relevant}

This is the first time that Discourse \& Society has devoted a special issue entirely to papers that come out of the emerging discipline of discursive psychology. In this paper I will try briefly to set out what is distinctive about discursive psychology in relation to the broader interdisciplary field of discourse studies and some of the ways it contributes to critical social analysis. This will inevitably be schematic and contentious, but is intended to supplement the depth of the papers that came before.

\section{What is discursive psychology?}

One way of characterising discursive psychology is as an approach that that treats psychology as an object in and for interaction. It is specifically called discursive psychology, then, as psychology is understood as part of discourse, as a feature of practices in a range of settings. The difference from traditional psychological perspectives is stark. Traditional psychological perspectives focus on giving a technical account of the actual psychological states, processes and entities that underpin (and thereby partly explain) action. Discursive psychology (DP) focuses on psychology from the position of participants - it considers their practical and situated constructions, terms, orientations, and displays. Using the classic linguistic distinction, DP considers psychology in fundamentally emic terms, eschewing the etic perspective that is standard in cognitivist and social cognitivist psychology. From its perspective the traditional objects and distinctions of cognitivist psychology start to lose sense and a radically different terrain of psychology comes into view. What sustains the coherence of the enterprise of discursive psychology is not the idea of a mental space to be populated by expert research but the massive significance of psychological constructions and notions in human affairs. 
Insofar as psychology is an object in discursive psychology it is practical, accountable, situated, embodied and displayed. Let me take these elements in turn. In DP psychology is...

...PRACTICAL

Psychology in DP is first and foremost something practical. Psychology in this sense is bound up with peoples' practices. Descriptions (of psychological, material or social objects) can be studied for the way they are invoked in activities such as blaming, complementing, inviting and so on (Potter, 1996). The psychological categories that make up the mental thesaurus can be studied as a kitbag of resources for doing things. For example, not remembering can be a resource for building or resisting an accusation (Lynch \& Bogen, 2005); a construction of 'boiling anger' can be used to establish the extremity and inappropriate nature of provocation (Edwards, 1997); the moderators use of a 'belief' construction in a focus group questions can encourage quick answers and discourage accounts and 'don't know' responses (Puchta \& Potter, 2004). This practical focus is a contrast to the more traditional psychological focus on perception, information processing and understanding. This practical focus is one major reason for DP research to have moved away from the analysis of open-ended interviews and on to the analysis of situated interaction recorded in natural settings.

\section{...ACCOUNTABLE}

A major element of the way psychology is woven into everyday practices is through the focus on accountability. How are individuals (or collectivities, organizations, or intraindividual entities) constructed as sites of responsibility? The focus on accountability typically works on two levels at once. First, there is speaker's construction of agency and accountability in the reported events (who or what should be blamed, complimented, and so on). Second, there is the speaker's construction of their own agency and accountability, 
including what they are doing through speaking. Often these two levels of accountability are closely bound together such that speakers can construct their own accountability via the construction of others' and vice versa (Edwards \& Potter, 1992). For example, Locke and Edwards (2003) studied the way President Clinton's constructions of Monica Lewinsky’s actions, emotions and motivations were reflexively and constructively linked to his own accountability.

\section{...SITUATED}

In DP psychology is situated in three senses. First, psychological concerns, orientations and categories are studied as embedded in interaction. Such an analysis draws on the methods and findings of conversation analysis. For example, take the traditional social psychological category of 'attitude' - a relatively enduring mentally encoded construct. DP radically reworks the notion of attitudes by focusing on situated evaluations (Potter, 1998; Wiggins \& Potter, 2003), drawing on Pomerantz' (1984) foundational work on assessments in talk. Second, psychological concerns, orientations and categories can be rhetorically oriented. For example, the construction of a particular evaluation (of the British royal family, in an argument, say) may be built to counter an alternative (Billig, 1996). Third, psychological concerns, orientations and categories are situated institutionally, in the practices of relationship counselling talk, family chat, courtroom summaries and so on. The primary analytic focus for analysing this third sense of situation is how psychological matters are introduced, constructed and made relevant to the setting's business (Edwards \& Potter, 2001).

\section{...EMBODIED}

DP focuses on discourse. As a perspective it holds back from what might superficially appear to be the direct study of embodiment (as seen in parts of experimental social cognition, for example, or in some traditions of the sociology of the body, or in some 
ethnographies). The reason for this is that such an approach dislocates embodiment from participants' own constructions and orientations. Instead in DP embodiment comes in through analysis of situated constructions of the body (as in Hepburn \& Wiggins, 2005, this volume), through the procedural unfolding of talk (as in Wiggins, 2002), or through video analysis of embodied interaction that, crucially, treats orientations and constructions as a primary analytic resources (as in Heath et al., 1999).

\section{...DISPLAYED}

For a range of conceptual, theoretical and analytic reasons DP rejects the John Locke picture of an inner, private psychology for which language serves as the conduit for transporting thoughts between minds. This is what Harris (1988) calls the telementation view of language. In its place DP focuses on psychology as something displayed in talk and interaction. DP here is building on Wittgenstein's (1953) critique of the idea of a private language, Coulter's (1990) sociology of mind and, most fundamentally, Sacks' (1992) project for understanding interaction that emphasised that language must be understandable and learnable. From Sacks' perspective mind, intentions, understanding and so on are part of interaction through their current hearability in the interaction itself. Rather than seeing such things as lying behind the talk they are seen as features visible in the talk itself. It radically counters the traditional psychological dualism of inner and outer. For example, the important cognitive psychological idea of shared understanding has been understood in terms of displays involving collaborative sentence production (Sacks, 1992), in terms of the procedural role of the turn and repair organization of talk (Schegloff, 1992), and in terms of how the basis for ongoing interaction is constructed in talk (Edwards, 1999). These traditions are discussed in detail in Potter and te Molder (2005).

DP is not an alternative analytic approach to the topic of cognition. It is a thoroughgoing respecification of cognition in particular and psychology more generally. The 
centrepiece of this respecification is DP's emphasis on psychology's practical and interactional role and the associated methodological move to focusing on the analysis of naturalistic discourse in everyday and institutional settings.

\section{Discursive Psychology and the field of Discourse Studies}

The thoroughgoing respecification of the psychological in DP puts it at odds analytically with alternative perspectives in discourse studies (some strands of sociolinguistics, some kinds of discourse process work, some styles of critical discourse analysis) that link studies of interaction to psychological processes or representations. See, for example, Edwards \& Potter (1993) on discourse processes work; Potter (1996) on critical discourse analysis, and Potter \& Edwards (2001) on sociolinguistics. An important part of the contrast with these approaches comes from the aim in DP to work with a consistent constructionist perspective that recognizes the contingency of descriptions and their involvement with practices. It is this consistent constructionism that provides part of the distinctive take on issues of 'psychology' as well as a range of topics such as 'context', 'material objects', 'embodiment'.

Constructionism is one of the things that sets DP apart from some strands of ethnomethodology and conversation analysis. However, the contrast is a complex one. There are, of course, differences between 'classic' ethnomethodology and Garfinkel's more recent programme, and between Sacks' earlier interest in membership categorization and the broader conversation analytic tradition he founded. This makes any simple comparison with DP difficult. Moreover, the constructionism in DP is itself a rather specific tradition. It developed out of problematics in sociology of scientific knowledge (Ashmore, 1989) focused on the constructive role of descriptions and versions. This sets it apart from the phenomenological social constructionism of Berger and Luckmann (1966). Indeed, Berger 
and Luckmann offer more of a cognitivist position in their focus is on the construction of an individual's experience. They do not consider how constructions (in talk and texts, in settings) of that 'experience' are used to do things, which would be a more DP project. Within ethnomethodology there is a long tradition of considering fact construction (most notably in the studies collected in Smith, 1990) and Sacks' earliest work was focused on the topic of description (Sacks, 1963). Hutchby and Wooffitt (1998) provide an account what a conversation analytic approach to fact construction might look like. Nevertheless, some ethnomethodologists argue strongly against constructionist positions (Button \& Sharrock, 1993).

Another potential difference arises in the theorizing of cognition. DP is not a cognitivist perspective. That is, it is not an attempt to explain actions by reference to underlying cognitive states or processes. However, the concepts, entities and distinctions of cognition are a major topic on two levels. First, studies consider the wide range of ways that cognitive language is used in settings such as neighbour disputes or child protection calls (Stokoe \& Hepburn, 2005; Hepburn \& Wiggins, 2005, this volume). Second, studies consider ways in which psychological methods and instruments reproduce cognitivism by failing to analytically encompass the way cognitive talk is oriented to action (see, for example, Antaki, 2004, and Auburn, 2005, this volume). Discourse workers have also developed different ways of engaging with, and reconsidering issues of psychodynamics and the unconscious (Billig, 1999; Wetherell, 2003).

This focus on cognitive concepts and distinctions in practice is distinct from some approaches from ethnomethodology and conceptual analysis. For example, Coulter (1999) has criticized DP for taking an empirical and discourse analytic rather than an apriori approach, and for not offering a corrective to mistaken cognitive constructions whether in academic, institutional or everyday settings. DP researchers have argued that the indexical 
and rhetorically oriented features of cognitive constructions means that conceptual analysis, while important, is not sufficient for analytic work (Edwards \& Potter, 2005; Potter \& Edwards, 2003). When people talk on the proposed and oriented-to basis that their words express inner thoughts and feelings, in counselling say, this is an analytic topic for DP rather than something to be corrected. Nevertheless, DP is much closer to some other strands in ethnomethodological work addressed to, and respecifying, cognition such as Lynch \& Bogen (2005).

The relationship with conversation analysis is equally complex. One way of understanding conversation analysis is as providing a consistently non-cognitive analytic perspective that is concerned with the mind in terms of formulations and displays embedded in the turn and sequence organization of conversation. Sacks' very first published lecture advocates the analysis of interaction independently of any concerns about the cognitive basis of what might be going on (1992, p. 11). For the most part conversation analysts have not been focused on issues of mind cognition. Yet where they have addressed such issues there has been some ambivalence over the role of cognitive processes. For example, in recent discussions Drew (2005), Heritage (2005) and Pomerantz (2005) in different ways attempt to link interactional phenomena to underlying cognitive states rather than following a DP approach of understanding putatively cognitive phenomena in interactional terms.

\section{Discursive Psychology and Critique}

This short article will end with some brief observations about the status of critique in discursive psychology, highlighting its enduring interest in a cluster of issues to do with categories and prejudice, its debates with traditional cognitivist approaches to psychology, and its interest in psychology and institutions. 


\section{CATEGORIES AND PREJUDICE}

One of the first critical themes in the style of discourse analysis that evolved into discursive psychology was focused on issues to do with racism, prejudice and minority groups (Potter \& Wetherell, 1987; Wetherell \& Potter, 1992; Wetherell, et al., 1987). Much of this early work used open-ended interviews with the aim of identifying interpretative repertoires and practices. The current collection shows two kinds of evolution in this work. First, Tileagă (2005, this volume) has worked primarily with open-ended interviews in his analysis of the management of producing extreme accounts against Romanies. A feature of his study is its careful, conversation analytically informed, analysis of the interview talk (cf. Edwards, 2003). It avoids a number of the difficulties that have been highlighted in recent qualitative work using open-ended interviews (Potter \& Hepburn, 2005). Second, Eriksson and Aronsson (2005, this volume) and Sneijder and te Molder (2005, this volume) illustrate the way that categories and issues to do with prejudice can be studied through studying natural settings where such things come up and are managed.

\section{CRITIQUES OF COGNITIVISM}

All of the papers in this special issue show the continuing development of a noncognitivist approach to psychological matters. They do this in different ways. For example, Stokoe and Hepburn (2005, this volume) consider material where noise is reported. However, their analysis is worlds apart from the traditional cognitive psychology of noise that is focused on perception, thresholds and so on. Instead, they analyse the way noise is worked up in descriptions to provide legitimate concern for complaint. Auburn (2005, this volume) takes as its topic the way that semi-technical cognitive notions become bound up with the practices of participants. 


\section{PSYCHOLOGY AND INSTITUTIONS}

Most of the papers here show the value of working with materials collected from institutional settings. This allows researchers to address the way particular psychological (or 'psychological') terms and orientations have institutional roles in particular settings. This is a rather different approach to social organization than most late C20th social psychology, which aimed to identify the operation of generic social processes, independently of institutions or historical settings (Gergen, 1982). One of the aims of DP is to show the way institutions such as therapy, education, focus groups, court cases are characterised by specific 'psychological business'. Moreover, analyses of this kind can explicate both the specifics of the psychological business and the nature of the institution. For example, Stokoe and Hepburn's (2005, this volume) article on noise reports in NSPCC and neighbour mediation provides a way of explicating subtle differences in the considerations underlying interaction in these different institutions.

These are only some of the critical themes that can be illuminated by DP; Hepburn (2003) and Speer (2005) review further strands of work.

\section{References}

Ashmore, M. (1989). The reflexive thesis: Wrighting sociology of scientific knowledge. Chicago: University of Chicago Press.

Antaki, C. (2004). Reading minds or dealing with interactional implications, Theory \& Psychology, 14, 667-683.

Auburn, T. (2005). Narrative reflexivity as a repair device for discounting 'cognitive distortions' in sex offender treatment, Discourse \& Society, 16, **_**. 
Berger, P.L., \& Luckmann, T. (1966). The social construction of reality. Garden City: Doubleday.

Billig, M. (1996). Arguing and Thinking: A Rhetorical Approach to Social Psychology (2nd ed.). Cambridge: Cambridge University Press.

Billig, M. (1999). Freudian repression: Conversation creating the unconscious. Cambridge: Cambridge University Press.

Button, G. \& Sharrock, W. (1993). A disagreement over agreement and consensus in constructionist sociology. Journal for the Theory of Social Behaviour, 23, 1-25.

Coulter, J. (1990). Mind in action. Oxford: Polity.

Coulter, J. (1999). Discourse and mind. Human Studies, 22: 163-181.

Drew, (2005). Is confusion a state of mind? In H. te Molder \& J. Potter (Eds). Conversation and cognition (pp. 161-183). Cambridge; Cambridge University Press.

Edwards, D. (1997). Discourse and cognition. London and Beverly Hills, CA: Sage.

Edwards, D. (1999). Shared knowledge as a performative and rhetorical category. In J. Verschueren (Ed.), Pragmatics in 1998: Selected papers from the 6th International Pragmatics Conference, vol. 2 (pp. 130-141). Antwerp: International Pragmatics Association.

Edwards, D. and Potter, J. (1992). Discursive Psychology. London: Sage.

Edwards, D. and Potter, J. (1993). Language and causation: A discourse analytical approach to description and attribution, Psychological Review, 100, 23-41.Edwards \& Potter 92

Edwards, D. \& Potter, J. (2001). Discursive psychology. In A.W.McHoul \& M. Rapley (Eds). How to analyse talk in institutional settings: A casebook of methods (pp. 1224). London; Continuum International. 
Edwards, D. \& Potter, J. (2005). Discursive psychology, mental states and descriptions. In H. te Molder \& J. Potter (Eds). Conversation and cognition (pp. 241-259). Cambridge; Cambridge University Press.

Eriksson, K. \& Aronsson, K. (2005). 'We're really lucky': Co-creating 'us' and 'the Other' in school book talk, Discourse and Society, 16, *****.

Gergen, K. J. (1982). Toward transformation in social knowledge. New York: SpringerVerlag. (2nd edition: Sage, 1994).

Harris, R. (1988). Language, Saussure and Wittgenstein. London: Routledge

Heath, C.C., Hindmarsh, J. \& P. Luff. (1999) Isolation and interaction: the fragmented world of the train driver on London Underground. Sociology, 33, 555-575.

Hepburn, A. (2003). An introduction to critical social psychology. London: Sage.

Hepburn, A. and Wiggins, S. (2005). Size matters: Constructing accountable bodies in NSPCC helpline interaction, Discourse \& Society, 16, *****.

Heritage, J. (2005). Cognition in discourse. In H. te Molder \& J. Potter (Eds). Conversation and cognition (pp. 241-259). Cambridge; Cambridge University Press.

Hutchby, I., \& Wooffitt, R. (1998). Conversation analysis: Principles, practices and applications. Cambridge: Polity.

Locke, A., \& Edwards, D. (2003. Bill and Monica: Memory, emotion and normativity in Clinton's Grand Jury testimony. British Journal of Social Psychology, 42 (2), 239256.

Lynch, M. \& Bogen, D. (2005). 'My memory has been shredded': a non-cognitivist investigation of 'mental' phenomena. In H. te Molder \& J. Potter (Eds). Conversation and cognition (pp. 226-240). Cambridge; Cambridge University Press.

Pomerantz, A.M. (1984). Agreeing and disagreeing with assessments: Some features of preferred/dispreferred turn shapes. In J.M. Atkinson \& J. Heritage (Eds.), Structures 
of social action: Studies in conversation analysis (pp. 57-101). Cambridge: Cambridge University Press.

Pomerantz, A. (2005). Using participants' video stimulated comments to complement analyses of interactional practices. In H. te Molder \& J. Potter (Eds). Conversation and cognition (pp. 93-113). Cambridge; Cambridge University Press.

Potter, J. (1996). Representing Reality: Discourse, Rhetoric and Social Construction. London; Sage.

Potter, J. \& Edwards, D. (2001). Sociolinguistics, cognitivism and discursive psychology. In N. Coupland, S. Sarangi, \& C. Candlin (Eds.) Sociolinguistics and Social Theory (pp. 88-103). London; Longman.

Potter, J. \& Edwards, D. (2003). Rethinking cognition: On Coulter, discourse and mind, Human Studies, 26, 165-181.

Potter, J. \& Hepburn, A. (2005). Qualitative interviews in psychology: Problems and prospects, Qualitative Research in Psychology.

Potter, J. \& te Molder, H. (2005). Talking cognition: Mapping and making the terrain. In H. te Molder \& J. Potter (Eds). Conversation and cognition (pp. 1-54). Cambridge; Cambridge University Press.

Potter, J. and Wetherell, M. (1987). Discourse and Social Psychology: Beyond Attitudes and Behaviour. London: Sage.

Puchta, C. \& Potter, J. (2004). Focus Group Practice. London: Sage.

Sacks, H. (1963). Sociological description. Berkeley Journal of Sociology, 8, 1-16.

Sacks, H. (1992). Lectures on conversation. Vols. I \& II, edited by G. Jefferson. Oxford: Basil Blackwell.

Schegloff, E.A. (1992) Repair after next turn: The last structurally provided defense of intersubjectivity in conversation, American Journal of Sociology, 98:1295-1345 
Smith, D. (1990). Texts, facts and femininity: Exploring the relations of ruling. London: Routledge.

Snijder, P. \& te Molder, H. (2005). Moral logic and logical morality: Attributions of responsibility and blame in online conversations on veganism, Discourse \& Society, $16, * *_{-} * *$.

Speer, S. (2005). Gender talk: Feminism, discourse and conversation analysis. London: Palgrave.

Stokoe, E. H. \& Hepburn, A. (2005). 'You can hear a lot through the walls: Noise formulations in neighbour complaints, Discourse \& Society, 16, **_**.

Tileagă, C. (2005). Accounting for extreme prejudice and legitimating blame in talk about the Romanies, Discourse \& Society, 16, *****.

Wetherell, M. (2003). Paranoia, ambivalence and discursive practices: Concepts of position and positioning in psychoanalysis and discursive psychology. In R. Harré and F. Moghaddam (Eds). The self and others: Positioning individuals and groups in personal, political and cultural contexts. New York: Praeger/Greenwood Publishers.

Wetherell, M. and Potter, J. (1992). Mapping the Language of Racism: Discourse and the Legitimation of Exploitation. Hemel Hempstead: Harvester/Wheatsheaf and New York: Columbia University Press.

Wetherell, M., Stiven, H. and Potter, J. (1987). Unequal egalitarianism: A preliminary study of discourses concerning gender and employment opportunities, British Journal of Social Psychology, 26, 59-72.

Wiggins, S. (2002). Talking with your mouth full: Gustatory Mms and the embodiment of pleasure, Research on Language and Social Interaction, 35, 311-336. 
Wiggins, S. \& Potter, J. (2003). Attitudes and evaluative practices: Category vs. item and subjective vs. objective constructions in everyday food assessments, British Journal of Social Psychology, 42, 513-531.

Wittgenstein, L. (1953/1958). Philosophical investigations. Trans. G.E.M. Anscombe. Oxford: Blackwell. 2nd Edition, 1958. 